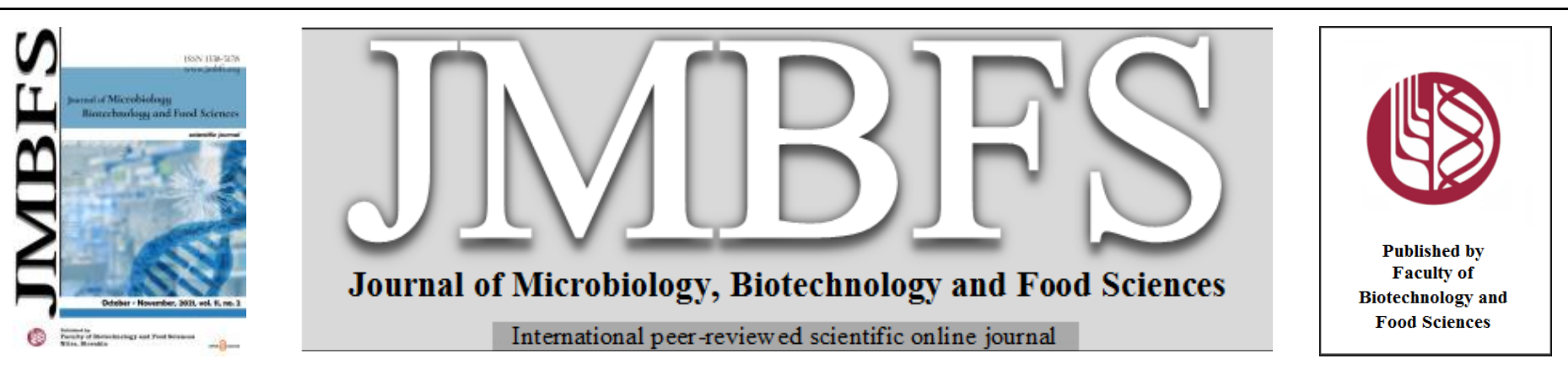

\title{
STATISTICAL OPTIMIZATION OF ALKALINE LIPASE PRODUCTION BY EXTREME HALOPHILIC ARCHEAN NATRIALBA ASIATICA
}

\author{
Maryam Pirghorbani ${ }^{l}$ and Mehdi Ebrahimi ${ }^{* 2}$ \\ Address(es): \\ ${ }^{1}$ Department of Microbiology, Varamin-Pishva Branch, Islamic Azad University, Varamin, Iran \\ ${ }^{2}$ Department of Biochemistry and Biophysics, Varamin-Pishva Branch, Islamic Azad University, Pishva, Iran
}

*Corresponding author: ebrahimi@iauvaramin.ac.ir

https://doi.org/10.15414/jmbfs.1164

\section{ARTICLE INFO}

Received 11. 1.2019

Revised 30. 4. 2021

Accepted 11. 5. 2021

Published 1. 10. 2021

Regular article

OPEN $\partial_{\text {ACCESS }}$

\begin{abstract}
In this study, extreme halophilic archean Natrialba asiatica was utilized as a new source for lipase production. Lipases from halophilic archaea are appealing for utilization in assorted industrial and biotechnological applications. The optimum temperature and $\mathrm{pH}$ of $N$. asiatica lipase in the crude mixture were $50{ }^{\circ} \mathrm{C}$ and 10 , respectively. The growth conditions influencing lipase production were determined using a two-level fractional factorial Plackett-Burman design. Among the 9 factors screened, $\mathrm{MgCl}_{2}$ concentration, temperature, and shaking were found to be effective. The optimum levels of these factors for the production process were determined by employing the central composite design of response surface methodology. The $27 \mathrm{~g} \mathrm{~L}^{-1}$ of $\mathrm{MgCl}_{2}, 50{ }^{\circ} \mathrm{C}$, and $133 \mathrm{rpm}$ were determined as optimized conditions for lipase production. The enzyme activity increased from 3.39 to $6.1 \mathrm{U} \mathrm{mL}^{-1}$ using predicted optimum levels. These findings help understanding factors affecting the production of lipase by halo-archean $N$. asiatica. Moreover, using the optimized level of temperature, shaking, and $\mathrm{MgCl} 2$, it is possible to increase the production of valuable alkaline lipase by $N$. asiatica.
\end{abstract}

Keywords: Lipase, Natrialba asiatica, Plackett-Burman Design, Response Surface Methodology, Extreme halophilic archaea

\section{INTRODUCTION}

Lipases (triacylglycerol acyl-hydrolases, E.C. 3.1.1.3) catalyze the hydrolase reaction of triacylglycerol into fatty acids and glycerol. Lipases are also accomplished to catalyze the synthesis of esters from fatty acids and glycerol. Both reactions were performed at the water-insoluble substrate interface $\mathbf{( C .} \mathbf{H}$. Tan et al., 2015b). Moreover, lipases can catalyze interesterification, acidolysis, alcoholysis, and aminolysis reactions. They usually exhibit good chemoselectivity, regioselectivity, and enantioselectivity besides broad substrate specificity (Joseph et al., 2008). These broad specifications made lipases one of the powerful essentials in several biotechnological aspects including synthesis of biopolymer, biodiesel, pharmaceuticals, agro-chemicals, and flavor compounds (Jaeger \& Eggert, 2002). These daily growing applications lead to the demand for the lipases with new specificities and therefore the isolation of new lipases from new natural sources is increasing potential value (Hasan et al., 2009). Lipases are produced by many microorganisms and eukaryotes. Among microorganisms, bacteria, fungi, yeasts and actinomycetes are the most important producers of lipase. Microbial lipases are very useful commercially and are broadly used in several industries (Gupta et al., 2004; Sharma et al., 2014). Natrialba asiatica is a gram-negative, strongly lipolytic, and extreme halophilic coccobacillus isolated from beach sand in Japan. Optimum temperature and $\mathrm{pH}$ for growth are $50{ }^{\circ} \mathrm{C}$ and $6.6-7$, respectively. $\mathrm{NaCl}$ range for growth is from $2 \mathrm{M}$ to saturation, with an optimum at $4 \mathrm{M}$ (Hezayen et al., 2001). Extreme halophilic organisms are bacteria or archaea that requiring high salt conditions for growth (3.5-5 M NaCl) (Margesin \& Schinner, 2001). With some adaptations, the proteins of these organisms can remain active in high salt concentrations (Karan et al., 2012). These adaptations besides the existing robust nature of lipases make halophilic lipases especially attractive for industrial and biotechnological applications. Moreover, halophilic archaea use simple carbon sources and high salt concentrations favored for industrial simple production systems in which enclosed sterile conditions omitted (Hezayen et al., 2001). However, studies on halophilic lipase-producing organisms are limited. Currently, halophilic microorganisms, especially halo-archaea, have received a lot of attention for lipase production (Delgado-García et al., 2012; Litchfield, 2011; Schreck \& Grunden, 2013). The most common technique for the production of lipases is submerged fermentation (SmF) but solid-state fermentation (SSF) methods can be used also (Gupta et al., 2004; Sharma et al., 2014). Carbon and nitrogen sources, stimulators, activators, inhibitors, surfactants, the temperature of incubation, $\mathrm{pH}$ of production medium, inoculum source and level can affect the lipase production in both SmF and SSF. (Hasan et al., 2009). Also, the production of lipase by every microorganism has different dependencies. Some of the factors influencing the optimal growth of a microorganism not only do not play a role in lipase production but in some cases have a negative effect. In optimization processes, these factors must be replaced by inducers of lipase production to become an economic bioprocess (Chennupati et al., 2009). Nowadays, Plackett-Burman design (PBD) is employed for recognizing effective factors among numerous growth conditions (Cai et al., 2008; Sadeghi-Dastjerdi et al., 2019; Yele \& Desai, 2014). To achieve an optimum condition for production, combinatorial interactions of effectors are investigated using response surface methodology (RSM) (Chennupati et al., 2009). In this study, PDB was used to determine the effectors of lipase production from nutrition and culture parameters of $\mathrm{N}$. asiatica. The lipase production process was optimized using a model that had been introduced by RSM to gain higher lipase production and was compared with unoptimized process.

\section{MATERIAL AND METHODS}

\section{Microorganism and Preparation of inoculum}

Natrialba asiatica IBRC-M 10341 was obtained from the Iranian Biotechnology research center as an active culture. a loop full of the bacterial active colony was added aseptically to $25 \mathrm{~mL}$ of MGM $23 \%$ broth $(\mathrm{pH} 7.5)$ to prepare pre-culture. Pre-culture was incubated at $37^{\circ} \mathrm{C}$ for $48 \mathrm{~h}$ with shaking $(150 \mathrm{rpm})$. A volume of $50 \mathrm{ml}$ of broth culture medium was inoculated with $1 \mathrm{ml}$ of 48 -hour culture in a $250 \mathrm{ml}$ Erlenmeyer flask and incubated under similar conditions. The optical density of the culture was recorded every 24 hours at $600 \mathrm{~nm}$ and was used to plot the growth curve of N.asiatica. One optical density unit of bacterial culture was prepared with the appropriate amount of fresh culture after $36 \mathrm{~h}$ of incubation and was used for inoculation of the experimental flasks (Prajapati $\boldsymbol{e t}$ al., 2014)

\section{Lipase assay}

Lipase activity was measured using p-NPP as substrate (Vorderwülbecke $\boldsymbol{e t}$ al., 1992). Substrate solution was prepared by addition of $10 \mathrm{~mL} p$-NPP $(0.1 \mathrm{M})$ to a mixture of natrium deoxycholate $(207 \mathrm{mg})$ and Arabic gum $(100 \mathrm{mg})$ in $90 \mathrm{~mL}$ 
phosphate buffer $(0.05 \mathrm{M}, \mathrm{pH} 6.5)$. The reaction was started by mixing crude enzyme extract $(0.1 \mathrm{~mL})$ into substrate solution $(2.4 \mathrm{~mL})$. A solution of phosphate buffer (50 mM, pH 6.5) was used instead of crude enzyme extract to prepare the blank solution. The reaction mixture was incubated at $50{ }^{\circ} \mathrm{C}$ for 15 min and absorbance was recorded at $410 \mathrm{~nm}$. One enzyme unit (U) was defined as the lipase activity that liberates $1 \mu \mathrm{mol}$ of $\mathrm{p}$-NP per mL per minute under the standard assay conditions (Demir \& Tükel, 2010).

\section{Effect of temperature and $\mathrm{pH}$ on the lipase activity}

N. asiatica lipase activity at temperatures from 30 to $60{ }^{\circ} \mathrm{C}$ (with $5{ }^{\circ} \mathrm{C}$ intervals) was measured to determine the optimum temperature. The reaction mixture was incubated for 15 minutes at each temperature and absorbance was recorded at 410 $\mathrm{nm}$. To determine the $\mathrm{pH}$ profile of $N$. asiatica lipase, substrate solution was prepared in sodium phosphate buffer $(0.5 \mathrm{M}, \mathrm{pH} 7-8.5)$ and Britton-Robinson buffer $(0.5 \mathrm{M}, \mathrm{pH} 9-11)$ with 0.5 intervals

\section{Plackett-Burman design}

To determine the factors affecting production of $\mathrm{N}$. asiatica lipase, a two factoria Plackett-Burman (PB) method was used to design experiments. PB method design $\mathrm{n}+1$ experiments for $\mathrm{n}$ factors and statistically explain interactions between the factors (Plackett \& Burman, 1946). In this study, 9 parameter including olive oil $\left(\mathrm{g} \mathrm{L}^{-1}\right)$, lactose $\left(\mathrm{g} \mathrm{L}^{-1}\right)$, peptone $\left(\mathrm{g} \mathrm{L}^{-1}\right), \mathrm{MgCl}_{2}(\mathrm{M}), \mathrm{NaCl}(\mathrm{M})$, shaking (rpm), $\mathrm{pH}$ and incubation temperature $\left({ }^{\circ} \mathrm{C}\right)$, and time $(\mathrm{h})$ were used to design experiments. For each factor, 2 levels, high $(+)$ and low (-), with one central point was determined. A collection of 15 experiments were designed for 9 factors. All experiments were replicated three times and the average was used for statistical analysis. Minitab 17 (Stat-Ease Inc., USA) statistical software was used to design experiments and analysis of results in the PB method. Variables and their levels in PB design were represented in Table 1. The PB design is based on the following first-order polynomial equation:

$\mathrm{Y}=\beta_{\mathrm{o}}+\Sigma \beta \mathrm{Xi}$

Where, $\mathrm{Y}$, is the lipase activity; $ß \mathrm{o}$, is the model intercept; $\mathrm{Bi}$, is the linear coefficient; $\mathrm{Xi}$, is the level of the independent variable.

\section{Response surface methodology}

Significant factors obtained from $\mathrm{PB}$ design $\left(\mathrm{MgCl}_{2}\right.$, shaking, and temperature) were used for the optimization of lipase production based on the response surface methodology (RSM). In this methodology, a central composite design (CCD) was performed to explore the effect of these factors on lipase production. Each variable was considered at three levels. In central composite design, 8 cube points, 6 center points in the cube, and 6 axial point runs $(20$ different experiments) were designed (Table 2). Moreover, to evaluate the pure error, 5 replications at the centeral point were performed. The lipase activity $\left(\mathrm{U} \mathrm{mL}^{-1}\right)$ in each experiment was taken as a response. The relationship among variables was determined according to the following second-order polynomial equation:

$Y=\beta o+\Sigma \beta i x i+\Sigma \beta i i x i^{2}+\Sigma \beta i j x i x j, i=1,2,3 \ldots k$

Where, $\mathrm{Y}$, is the predicted response; $\mathrm{k}$, is the number of factor variables; ßo, is the model constant; $\beta i$, is the linear coefficient; $\beta i i$, is the quadratic coefficient; $B \mathrm{ij}$, is the interaction coefficient.

\section{Validation of the model}

Statistical significance of the polynomial model was evaluated using Fischer's Ftest. The coefficient of determination $\left(\mathrm{R}^{2}\right)$ was used for the evaluation of the quality of the represented model (Chennupati et al., 2009; Sumrin et al., 2011).

\section{Optimization of the variable's level}

The aim of the optimization process in this study was an increment in the production of lipase by $N$. asiatica. To achieve this, we set the temperature level between $30-50{ }^{\circ} \mathrm{C}$ that is the minimum and maximum growth temperature of $N$. asiatica. The best temperature in this range is $50{ }^{\circ} \mathrm{C}$ that was predicted by the model. Shaking and concentration of $\mathrm{MgCl}_{2}$ were also determined by the model as $133 \mathrm{rpm}$ and $27 \mathrm{~g} \mathrm{~L}^{-1}$, respectively. The predicted lipase activity by the model in $95 \%$ of confidence was $6.74 \mathrm{U} \cdot \mathrm{mL}^{-1}$.

\section{RESULTS AND DISCUSSION}

\section{Preparation of inoculum}

Factors such as inoculum size and growth profile can affect the amount of enzyme production by bacteria. In addition, the number of bacterial cells in the culture medium affects nutrient accessibility. As the time of bacterial culture increases, the concentration of growth inhibitory compounds also increases (Thakur et al., 2014). To overcome these limiting factors of lipase production and also to use a constant number of active bacteria in all experiments, a $N$. asiatica growth pattern was determined. According to Figure 1, absorbance in $600 \mathrm{~nm}$ increases up to 1.4 during $48 \mathrm{~h}$ and then remains nearly constant. After $144 \mathrm{~h}$, absorbance decreases due to the death of bacteria. We used $1 \mathrm{ml}$ of a $36 \mathrm{~h}$ bacterial culture with absorbance 1 in $600 \mathrm{~nm}$ to inoculate culture medium in all experiments (Prajapati et al., 2014).

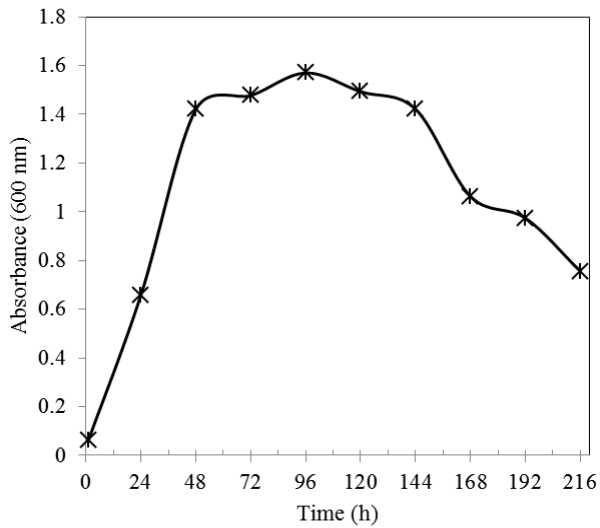

Figure 1 Growth profile of $N$. Asiatica during the different incubation times.

\section{Optimization of enzyme assay}

Changes in temperature and $\mathrm{pH}$ affect the activity of enzymes and therefore the measurement of enzyme activity should be done under optimal temperature and $\mathrm{pH}$ conditions. Therefore, to determine the optimum temperature and $\mathrm{pH}$, the activity of $N$. asiatica lipase was measured at different temperatures and $\mathrm{pH}$ (Figure 2). According to the $\mathrm{pH}$ profile, the maximum activity of $N$. asiatica lipase was obtained at $\mathrm{pH} 10$ and so this enzyme could be considered as an alkaline lipase. Lipases with similar optimum $\mathrm{pH}$ range were reported from other sources such as Staphylococcus sp. strain ESW (pH 9-13), Pseudomonas aeruginosa ( $\mathrm{pH}$ 9), Bacillus sonorensis 4R ( $\mathrm{pH} 9)$, and some others (Bhosale $\boldsymbol{e}$ al., 2016; Cherif et al., 2011; Karadzic et al., 2006). Maximum activity of $N$. asiatica lipase $\left(50^{\circ} \mathrm{C}\right)$ is like to the other moderate thermophile lipases from Spirulina platensis $\left(45{ }^{\circ} \mathrm{C}\right)$, Penicillium camemberti Thom PG-3 $\left(48{ }^{\circ} \mathrm{C}\right)$, and Aspergillus niger F044 $\left(45^{\circ} \mathrm{C}\right)$ (Demir \& Tükel, 2010; Shu et al., 2007; T. Tan et al., 2004).
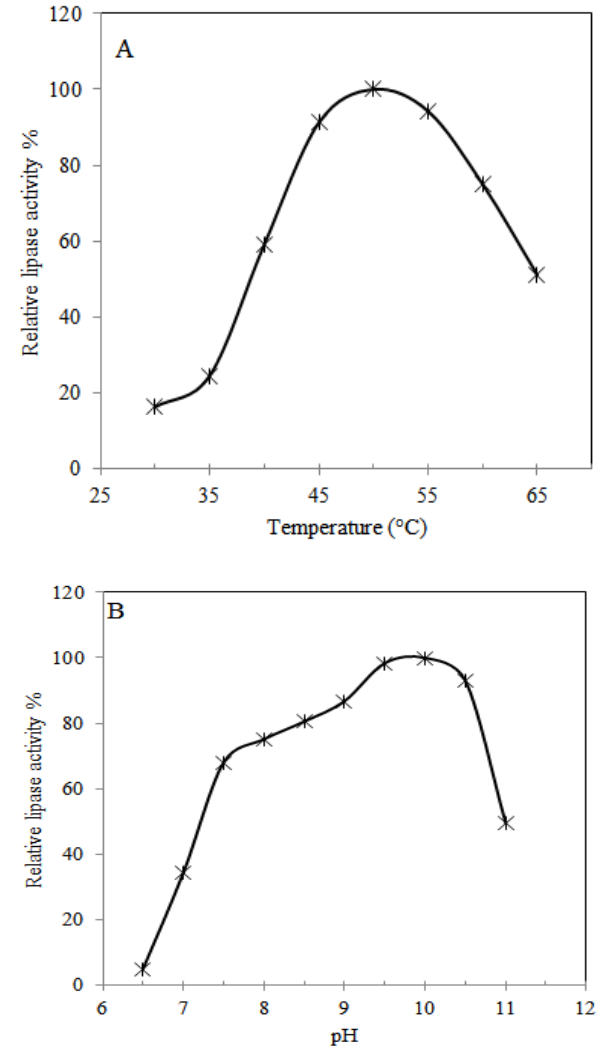

Figure 2 Activity of $N$. asiatica lipase in different temperatures (A) and $\mathrm{pH}$ (B). 


\section{Detection of significant factors using PB design}

The submerged culture method has been widely used to produce lipase by various bacteria (Sharma et al., 2014). Optimal culture conditions and the nutritiona needs of each microorganism should be considered to increase lipase production. The most important parameters that affect the amount of lipase production are the type and concentration of carbon and nitrogen sources, temperature and $\mathrm{pH}$ of bacterial growth and the concentration of dissolved oxygen (Elibol \& Ozer, 2000). In conventional methods for determining the effective parameters in the production of a product by a microorganism, it was only possible to evaluate one parameter in each experiment. In other words, only one parameter is changed in each evaluation and the other parameters are constant. This method is very time consuming and expensive in cases where the number of factors to be evaluated is large. Today, the Plackett-Burman (PB) method is widely used as a powerful method to evaluate and determine the effective parameters in a process (Chennupati et al., 2009; Heydari et al., 2012; Liu et al., 2011; Pareek et al., 2011; Prajapati et al., 2014; Yele \& Desai, 2014). One of the advantages of this method is the reduction of the number of tests required to determine the effective parameters.

In the present study, olive oil, lactose, peptone, $\mathrm{MgCl}_{2}, \mathrm{NaCl}, \mathrm{pH}$, shaking, and incubation time and temperature as independent variables were investigated in the PB design. The results of experiments designed by PB method and analysis of variance (ANOVA) are shown in Table 1 and Table 2, respectively.

The effect of variables in the lipase production by $N$. asiatica was represented as the following mathematical model:

Lipase activity $\left(\mathrm{U} \mathrm{mL}^{-1}\right)=2.62-0.0442$ temperature $-0.135 \mathrm{pH}-0.01436$ Shaking- 0.01074 Incubation time $+0.00158 \mathrm{NaCl}+0.2114 \mathrm{MgCl}_{2}+0.0575$ Lactose- 0.042 Peptone +0.0367 Olive oil $+0.575 \mathrm{Ct} \mathrm{Pt}$

The F- and P-value of the assumed model are 6.35 and 0.045 , respectively. These values mean that the model is significant. The confidence of determination $\left(\mathrm{R}^{2}\right)$ of the PB design (94.08\%) represented that the mathematical model can fit $94.08 \%$ of total variables in the range of studied values.

The p-value and F-value show the significance of variables at the confidence level. The significant variables (with p-value less than 0.05 and high F-value) (Pareek et al., 2011) are represented in Table 2. According to Table 2, three parameters including temperature, shaking, and $\mathrm{MgCl}_{2}$ were known as significant. This means that olive oil, lactose, and peptone used in the culture of $N$. asiatica as carbon and nitrogen sources have not effect on lipase production and could be replaced by other components. Since $N$. asiatica is a halophilic bacterium, high $\mathrm{NaCl}$ concentration is essential for bacterial growth but not for lipase production. The dependency of lipase production on carbon sources different between species. Olive oil was known as a lipase production inducer in different bacterial sources (Mobarak-Qamsari et al., 2011; Stergiou et al., 2012 Yele \& Desai, 2014). In N. asiatica, olive oil has not a significant effect on lipase production like in some other reports (Burkert, 2004; Chennupati et al., 2009, Ito et al., 2001). Lactose is another carbon source that was not determined as an effective factor. This result is similar to the study on the production of cold-active lipase production by marine bacterium Wangia sp. C52 (Liu et al., 2011). In the study reported by Tianway et al., lactose was the optimal carbohydrate for lipase production by $P$. camemberti Thom (C. H. Tan et al., 2015a). Rajendran et al. used PBD to investigate the effect of 12 medium components in lipase production by Bacillus sphaericus and report glucose, olive oil, peptone, $\mathrm{NaCl}$ and $\mathrm{MgSO}_{4} \cdot \mathrm{H}_{2} \mathrm{O}$ as effective factors (Rajendran \& Thangavelu, 2007). Comparison of the results of these studies with our finding shows that there is a different dependency of medium components for the production of lipase among different bacterial species and so, determining the significant parameters is the most important step in designing a production process.

Table 1 The Placket-Burman design for detection of significant factors affecting lipase production in N. asiatica.

\begin{tabular}{|c|c|c|c|c|c|c|c|c|c|c|c|c|c|c|c|c|c|c|c|c|}
\hline \multirow[t]{2}{*}{ Run Order } & \multicolumn{2}{|c|}{ Temp. $\left({ }^{\circ} \mathrm{C}\right)$} & \multicolumn{2}{|c|}{$\mathrm{pH}$} & \multicolumn{2}{|c|}{ Shaking (rpm) } & \multicolumn{2}{|c|}{ Inc. time (h) } & \multicolumn{2}{|c|}{$\begin{array}{l}\mathrm{NaCl} \\
\left(\mathrm{g} \mathrm{L}^{-1}\right)\end{array}$} & \multicolumn{2}{|c|}{$\begin{array}{l}\mathrm{MgCl}_{2} \\
\left(\mathrm{~g} \mathrm{~L}^{-1}\right)\end{array}$} & \multicolumn{2}{|c|}{$\begin{array}{c}\text { Lactose } \\
\left(\mathrm{g} \mathrm{L}^{-1}\right)\end{array}$} & \multicolumn{2}{|c|}{$\begin{array}{c}\text { Peptone } \\
\left(\mathrm{g} \mathrm{L}^{-1}\right)\end{array}$} & \multicolumn{2}{|c|}{$\begin{array}{l}\text { Olive oil } \\
\left(\mathrm{mL} \mathrm{L} \mathrm{L}^{-1}\right)\end{array}$} & \multicolumn{2}{|c|}{$\begin{array}{c}\text { Lipase activity } \\
\left(\mathrm{U} \mathrm{mL}^{-1}\right)\end{array}$} \\
\hline & EV & level & EV & level & EV & level & $\mathrm{EV}$ & level & $\mathrm{EV}$ & level & EV & level & EV & level & EV & level & $\mathrm{EV}$ & level & Observed & Predicted \\
\hline$\overline{1}$ & 50 & + & 8.5 & + & 190 & + & 24 & - & 204 & + & 26 & + & 15 & - & 6.25 & + & 15 & - & 2.97 & 3.18 \\
\hline 2 & 50 & + & 6.5 & - & 190 & + & 72 & + & 164 & - & 26 & + & 15 & - & 3.75 & - & 15 & - & 3.31 & 3.09 \\
\hline 3 & 30 & - & 8.5 & + & 190 & + & 24 & - & 204 & + & 20 & - & 15 & - & 3.75 & - & 25 & + & 3.60 & 3.38 \\
\hline 4 & 50 & + & 8.5 & + & 110 & - & 72 & + & 204 & + & 20 & - & 25 & + & 3.75 & - & 15 & - & 3.11 & 3.26 \\
\hline 5 & 30 & - & 6.5 & - & 110 & - & 72 & + & 204 & + & 26 & + & 15 & - & 6.25 & + & 25 & + & 5.22 & 5.42 \\
\hline 6 & 30 & - & 8.5 & + & 190 & + & 72 & + & 164 & - & 26 & + & 25 & + & 3.75 & - & 25 & + & 4.32 & 4.58 \\
\hline 7 & 40 & 0 & 7.5 & 0 & 150 & 0 & 48 & 0 & 184 & 0 & 23 & 0 & 20 & 0 & 5 & 0 & 20 & 0 & 4.73 & 4.57 \\
\hline 8 & 50 & + & 8.5 & + & 110 & - & 72 & + & 164 & - & 20 & - & 15 & - & 6.25 & + & 25 & + & 3.09 & 2.94 \\
\hline 9 & 50 & + & 6.5 & - & 190 & + & 24 & - & 164 & - & 20 & - & 25 & + & 6.25 & + & 25 & + & 2.95 & 3.09 \\
\hline 10 & 50 & + & 6.5 & - & 110 & - & 24 & - & 204 & + & 26 & + & 25 & + & 3.75 & - & 25 & + & 5.89 & 5.68 \\
\hline 11 & 40 & 0 & 7.5 & 0 & 150 & 0 & 48 & 0 & 184 & 0 & 23 & 0 & 20 & 0 & 5 & 0 & 20 & - & 4.84 & 4.57 \\
\hline 12 & 40 & 0 & 7.5 & 0 & 150 & 0 & 48 & 0 & 184 & 0 & 23 & 0 & 20 & 0 & 5 & 0 & 20 & - & 4.15 & 4.57 \\
\hline 13 & 30 & - & 6.5 & - & 110 & - & 24 & - & 164 & - & 20 & - & 15 & - & 3.75 & - & 15 & 0 & 4.05 & 4.30 \\
\hline 14 & 30 & - & 8.5 & + & 110 & - & 24 & - & 164 & - & 26 & + & 25 & + & 6.25 & + & 15 & 0 & 6.06 & 5.77 \\
\hline 15 & 30 & - & 6.5 & - & 190 & + & 72 & + & 204 & + & 20 & - & 25 & + & 6.25 & + & 15 & 0 & 3.36 & 3.21 \\
\hline
\end{tabular}

Legend: EV: experimental value; Temp: temperature; Inc: incubation

Table 2 Analysis of Variance for experimental results respects to lipase activity of Placket-Burman design.

\begin{tabular}{lccccc}
\hline Source & DF & Adj SS & Adj MS & F-Value & P-Value \\
\hline Model & 10.000 & 14.387 & 1.439 & 6.350 & 0.045 \\
Linear & 9.000 & 13.592 & 1.510 & 6.670 & 0.042 \\
$\quad$ Temperature & 1.000 & 2.345 & 2.345 & 10.350 & 0.032 \\
pH & 1.000 & 0.219 & 0.219 & 0.970 & 0.382 \\
Shaking & 1.000 & 3.961 & 3.961 & 17.490 & 0.014 \\
Incubation time & 1.000 & 0.797 & 0.797 & 3.520 & 0.134 \\
$\quad \mathrm{NaCl}$ & 1.000 & 0.012 & 0.012 & 0.050 & 0.830 \\
$\mathrm{MgCl}_{2}$ & 1.000 & 4.829 & 4.829 & 21.320 & 0.010 \\
$\quad$ Lactose & 1.000 & 0.993 & 0.993 & 4.390 & 0.104 \\
$\quad$ Peptone & 1.000 & 0.033 & 0.033 & 0.150 & 0.722 \\
Olive oil & 1.000 & 0.404 & 0.404 & 1.780 & 0.253 \\
Curvature & 1.000 & 0.795 & 0.794 & 3.510 & 0.134 \\
Error & 4.000 & 0.906 & 0.226 & & \\
Lack-of-Fit & 2.000 & 0.629 & 0.314 & 2.270 & 0.306 \\
$\quad$ Pure Error & 2.000 & 0.277 & 0.139 & & \\
Total & 14.000 & 15.293 & & & \\
\hline
\end{tabular}

Legend: DF: Degree of Freedom, Adj SS: the adjusted sum of squares, Adj MS: adjusted mean of squares.

Standardized effects of variables were shown in the Pareto chart (Figure 3) According to the Pareto chart, significant factors have effects upper than the $\mathrm{t}$ value (2.776). Among the three significant factors, $\mathrm{MgCl}_{2}$ and temperature have the highest and lowest effects, respectively.

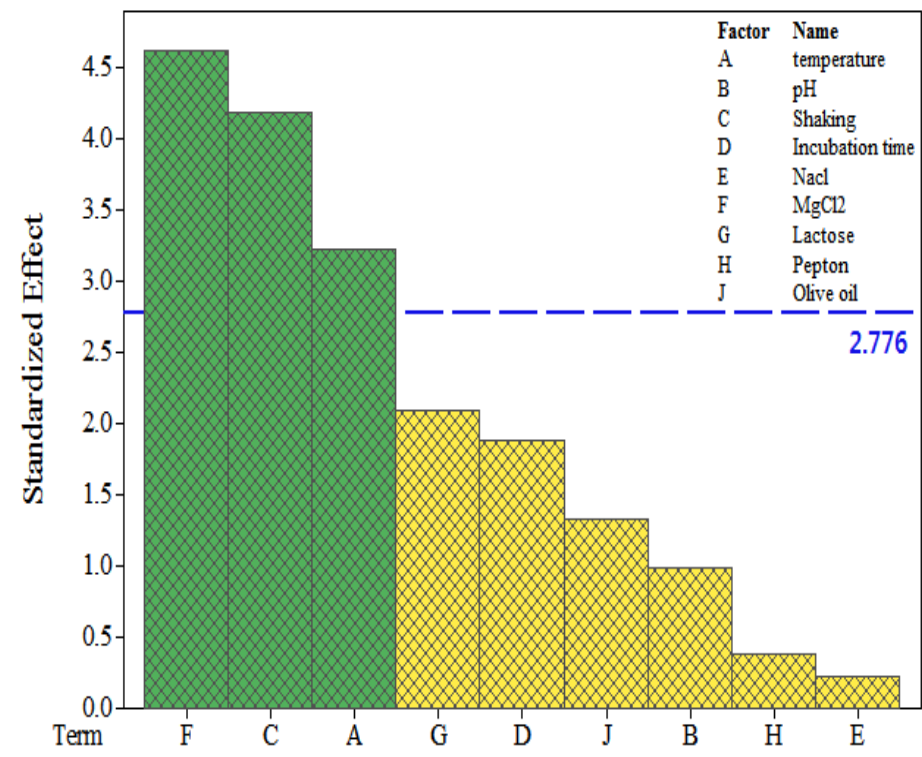

Figure 3 Pareto chart of the standardized effect of variables for the detection of significant factors for lipase production from $N$. asiatica. 


\section{Optimization of lipase production using RSM}

The response surface methodology (RSM) was used to investigate the interaction of effective parameters in the production of lipase by $N$. asiatica (temperature, vibration and magnesium). The predicted and observed values of the experiments designed based on CCD are shown in Table 3. The minimum and maximum lipase activity obtained in these experiments were 4.112 to $6.701 \mathrm{U} \mathrm{mL}^{-1}$, respectively.

\begin{tabular}{|c|c|c|c|c|c|c|c|c|}
\hline \multirow{2}{*}{ Run Order } & \multicolumn{2}{|c|}{ Temperature $\left({ }^{\circ} \mathrm{C}\right)$} & \multicolumn{2}{|c|}{ Shaking (rpm) } & \multicolumn{2}{|c|}{$\mathrm{MgCl}_{2}\left(\mathrm{~g} \mathrm{~L}^{-1}\right)$} & \multirow{2}{*}{ Observed } & \multirow{2}{*}{ Predicted } \\
\hline & actual & Coded & actual & Coded & actual & Coded & & \\
\hline 1 & 30 & -1 & 110 & -1 & 20 & -1 & 6.541 & 6.264 \\
\hline 2 & 50 & 1 & 110 & -1 & 20 & -1 & 6.065 & 5.809 \\
\hline 3 & 30 & -1 & 190 & 1 & 20 & -1 & 4.897 & 4.816 \\
\hline 4 & 50 & 1 & 190 & 1 & 20 & -1 & 4.582 & 4.361 \\
\hline 5 & 30 & -1 & 110 & -1 & 26 & 1 & 5.668 & 5.783 \\
\hline 6 & 50 & 1 & 110 & -1 & 26 & 1 & 6.701 & 6.317 \\
\hline 7 & 30 & -1 & 190 & 1 & 26 & 1 & 6.114 & 5.906 \\
\hline 8 & 50 & 1 & 190 & 1 & 26 & 1 & 6.269 & 6.440 \\
\hline 9 & 23 & -1.682 & 150 & 0 & 23 & 0 & 6.725 & 6.855 \\
\hline 10 & 57 & 1.682 & 150 & 0 & 23 & 0 & 6.647 & 6.921 \\
\hline 11 & 40 & 0 & 83 & -1.682 & 23 & 0 & 5.338 & 5.678 \\
\hline 12 & 40 & 0 & 217 & 1.682 & 23 & 0 & 4.499 & 4.564 \\
\hline 13 & 40 & 0 & 150 & 0 & 18 & -1.682 & 4.112 & 4.471 \\
\hline 14 & 40 & 0 & 150 & 0 & 28 & 1.682 & 5.770 & 5.814 \\
\hline-15 & 40 & 0 & 150 & 0 & 23 & 0 & 5.794 & 5.804 \\
\hline 16 & 40 & 0 & 150 & 0 & 23 & 0 & 5.867 & 5.804 \\
\hline 17 & 40 & 0 & 150 & 0 & 23 & 0 & 5.828 & 5.804 \\
\hline 18 & 40 & 0 & 150 & 0 & 23 & 0 & 5.847 & 5.804 \\
\hline 19 & 40 & 0 & 150 & 0 & 23 & 0 & 5.760 & 5.804 \\
\hline 20 & 40 & 0 & 150 & 0 & 23 & 0 & 5.799 & 5.804 \\
\hline
\end{tabular}

The ANOVA was used to investigate the effect of each variable on lipase production by linear, square, and 2-way interaction (Table 4). Considering F- and $\mathrm{P}$-value $(\mathrm{P}=<0.05)$, just temperature has not a significant effect in the linear model. While all other combinations of square and 2-way interactions of three variables are significant. The following second-order polynomial equation represents these effects in the production of lipase.

Lipase activity $\left(\mathrm{U} \mathrm{mL}^{-1}\right)=11.76-0.4942$ Temp- 0.0382 Shaking $+0.508 \mathrm{MgCl}_{2}+$ 0.003832 Temp*Temp- 0.000151 Shaking*Shaking-0.02599 $\mathrm{MgCl}_{2} * \mathrm{MgCl}_{2}+$ 0.00824 Temp* $\mathrm{MgCl}_{2}+0.003273$ Shaking* $\mathrm{MgCl}_{2}$

The F- and P-value for the model are 16.80 and 0.00 , respectively and therefore the model terms are significant.

Table 4 ANOVA for the central composite design based experiments

\begin{tabular}{cccccc}
\hline Source & DF & Adj SS & Adj MS & F-Value & P-Value \\
\hline Model & 8 & 9.554 & 1.194 & 16.800 & 0.000 \\
Linear & 3 & 3.683 & 1.228 & 17.270 & 0.000 \\
A & 1 & 0.005 & 0.005 & 0.070 & 0.791 \\
B & 1 & 1.498 & 1.498 & 21.080 & 0.001 \\
C & 1 & 2.179 & 2.179 & 30.670 & 0.000 \\
Square & 3 & 4.148 & 1.383 & 19.460 & 0.000 \\
A*A & 1 & 2.116 & 2.116 & 29.770 & 0.000 \\
B*B & 1 & 0.842 & 0.842 & 11.840 & 0.006 \\
C*C & 1 & 0.789 & 0.789 & 11.100 & 0.007 \\
2-Way Interaction & 2 & 1.723 & 0.862 & 12.120 & 0.002 \\
A*C & 1 & 0.489 & 0.489 & 6.880 & 0.024 \\
B*C & 1 & 1.234 & 1.234 & 17.360 & 0.002 \\
Error & 11 & 0.782 & 0.071 & & \\
Lack-of-Fit & 6 & 0.774 & 0.129 & 84.830 & 0.000 \\
Pure Error & 5 & 0.008 & 0.002 & & \\
Total & 19 & 10.335 & & & \\
\hline Legend: A: Temperature & $\mathrm{B}$ & $\mathrm{S}$ &
\end{tabular}

Legend: A: Temperature, B: shaking, $\mathrm{C}: \mathrm{MgCl}_{2}$

The coefficient of variations $\left(\mathrm{R}^{2}\right)$ always lies between 0 and 1 and shows the capability of the model to describe the variability in the response.

(Uma \& Satyanarayana, 2003). The closer $\mathrm{R}^{2}$ is to one, the greater the model's ability to predict results (Frank Ph. D, 1992). Considering the $\mathrm{R}^{2}$ value $(0.924)$ the confirmed model can describe $92.4 \%$ of the total variability within the range of values studied. In our study, there is an appropriate agreement between $\mathrm{R}^{2}$ (0.924) and adjusted $R^{2}(0.869)$. The adjusted $R^{2}$ corrects the $R^{2}$ value for the sample size and the number of terms in the model (Uma \& Satyanarayana, 2003) It means that experimental and predicted values for lipase production are enough to close together. The ability of the given model in the prediction of results can be investigated by comparing the actual results and predicted values in the same experiment. Figure 4 shows a good fit for actual and predicted values in the lipase production.

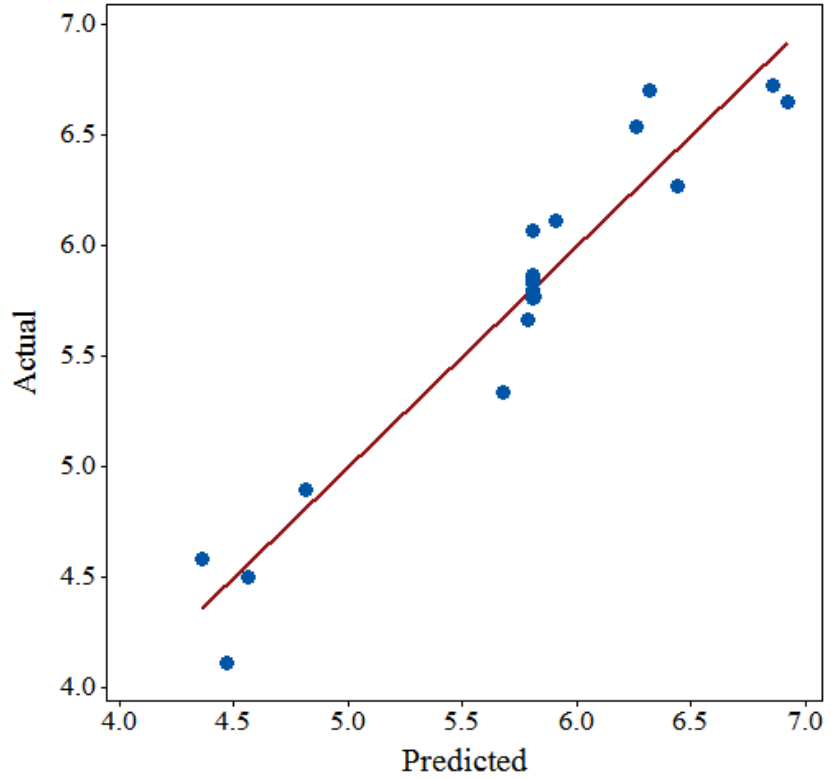

Figure 1 Scattering plot for actual results against predicted values of CCD experiments.

\section{Analysis of response surface methodology (RSM)}

The interactions of factors on lipase production by $N$. asiatica are shown in 3D plots. In each plot, one factor is constant and the other two factors change according to the values specified in the CCD. The surface of each curved plate shows the amount of change in lipase production.

Figure 5a shows the effect of shaking and temperature when $\mathrm{MgCl}_{2}$ concentration remaining constant. In each temperature, lipase activity increased with increment in shaking up to $150 \mathrm{rpm}$. But activity decreases in the shaking upper than 150 $\mathrm{rpm}$. The temperature has different effects. In each shaking value, lipase activity decreases with an increment in the temperature up to $40^{\circ} \mathrm{C}$. In the next step, we can see increments in the activity with the increase in temperature. According to the related contour plot for the mentioned condition (Figure 6a), maximum lipase activity obtains in shaking range from 90 to $150 \mathrm{rpm}$ and temperatures less than $25^{\circ} \mathrm{C}$ and more than $55^{\circ} \mathrm{C}$. In Figure $5 \mathrm{~b}$ simultaneous effects of temperature and $\mathrm{MgCl}_{2}$ in lipase production were investigated. Increments in $\mathrm{MgCl}_{2}$ concentration leads to an increase in lipase activity in all temperatures. Maximum activity of lipase acquires in $\mathrm{MgCl}_{2}$ and temperature upper than $24 \mathrm{~g} \mathrm{~L}^{-1}$ and 55 ${ }^{\circ} \mathrm{C}$, respectively (Figure 6b). As like as Figure 5a, similar effects of temperature can be seen in different concentrations of $\mathrm{MgCl}_{2}$. Figure $5 \mathrm{c}$ shows lipase activity in different levels of $\mathrm{MgCl}_{2}$ and shaking at constant temperature $\left(40{ }^{\circ} \mathrm{C}\right)$. The 
concentration of $\mathrm{MgCl}_{2}$ up to $23 \mathrm{~g} \mathrm{~L}^{-1}$ increases lipase activity in the shaking range from 90 to $150 \mathrm{rpm}$. More $\mathrm{MgCl}_{2}$ concentrations in similar shaking ranges decrease activity. In the shaking range from 150 to $210 \mathrm{rpm}$, lipase activity increased with increment in the concentration of $\mathrm{MgCl}_{2}$. The maximum activity obtained in broad ranges of $\mathrm{MgCl}_{2}$ concentrations and shaking speed from 21 to $28 \mathrm{~g} \mathrm{~L}-1$ and 90 to $200 \mathrm{rpm}$, respectively (Figure $6 \mathrm{c}$ ).

Predicted values of factors in the model were used in an experiment and the result was compared with non-optimized conditions. The optimized condition was $\mathrm{pH}$ 7.5 , incubation time $48 \mathrm{~h}, \mathrm{NaCl} 184 \mathrm{~g} \mathrm{~L}^{-1}$, lactose $20 \mathrm{~g} \mathrm{~L}^{-1}$, peptone $5 \mathrm{~g} \mathrm{~L}^{-1}$, olive oil $20 \mathrm{~mL} \mathrm{~L}^{-1}$, shaking $133 \mathrm{rpm}$, temperature $50^{\circ} \mathrm{C}$, and $\mathrm{MgCl}_{2} 26 \mathrm{~g} \mathrm{~L}^{-1}$. Lipase activity in the experiment under optimal conditions $\left(6.1 \mathrm{U} \mathrm{mL}^{-1}\right)$ was very close to the value predicted by the model $\left(6.74 \mathrm{U} \mathrm{mL}^{-1}\right)$. In addition, lipase activity increased by $98.8 \%$ under optimal conditions compared to non-optimized conditions $\left(3.39 \mathrm{U} \mathrm{mL}^{-1}\right)$. This result confirms that the model appropriately can define optimal levels of factors to increase production of lipase by $N$. asiatica.
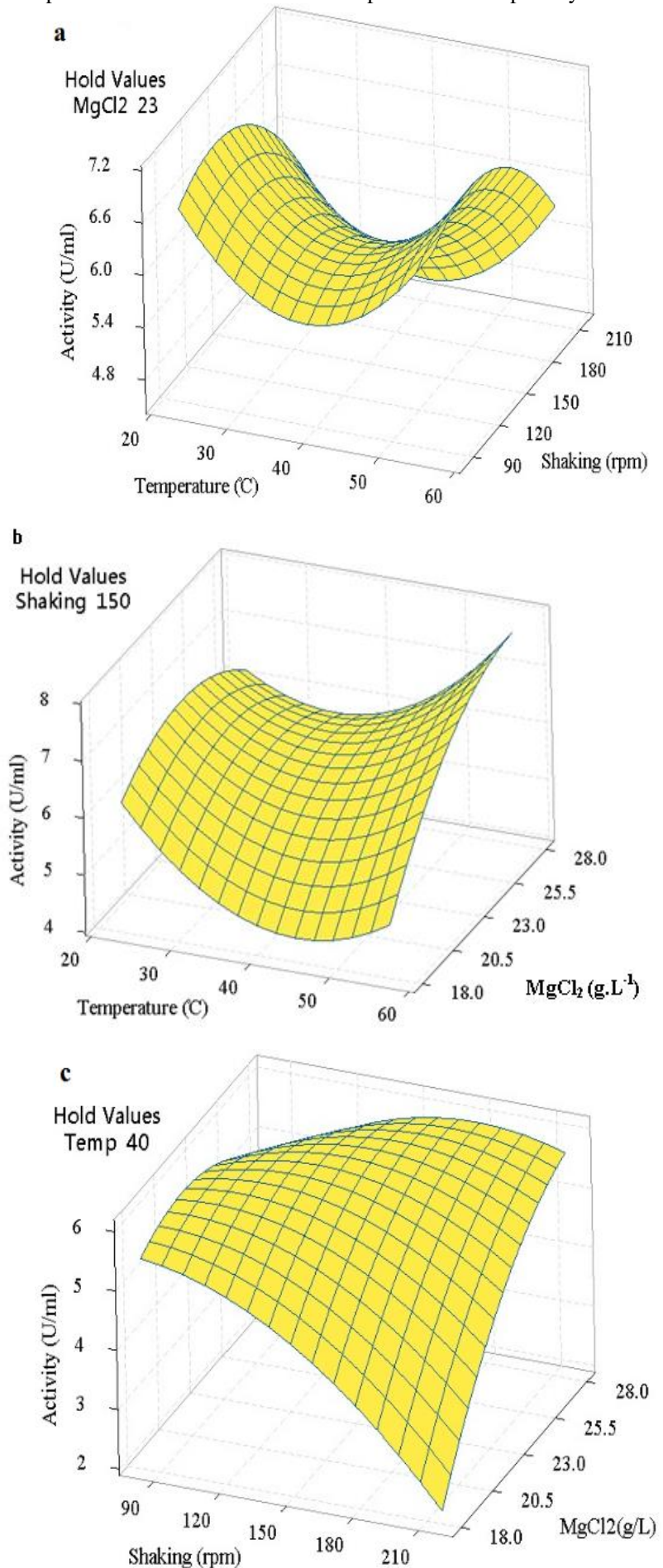

Figure 5 Surface plot for investigation of interactive effects of variables on lipase production. In each plot, one variable remains constant. The constant variables including $\mathrm{MgCl}_{2}\left(23 \mathrm{~g} . \mathrm{L}^{-1}\right)$ in (a) and shaking (150rpm) and temperature $\left(40^{\circ} \mathrm{C}\right)$ in (b) and (c), respectively.
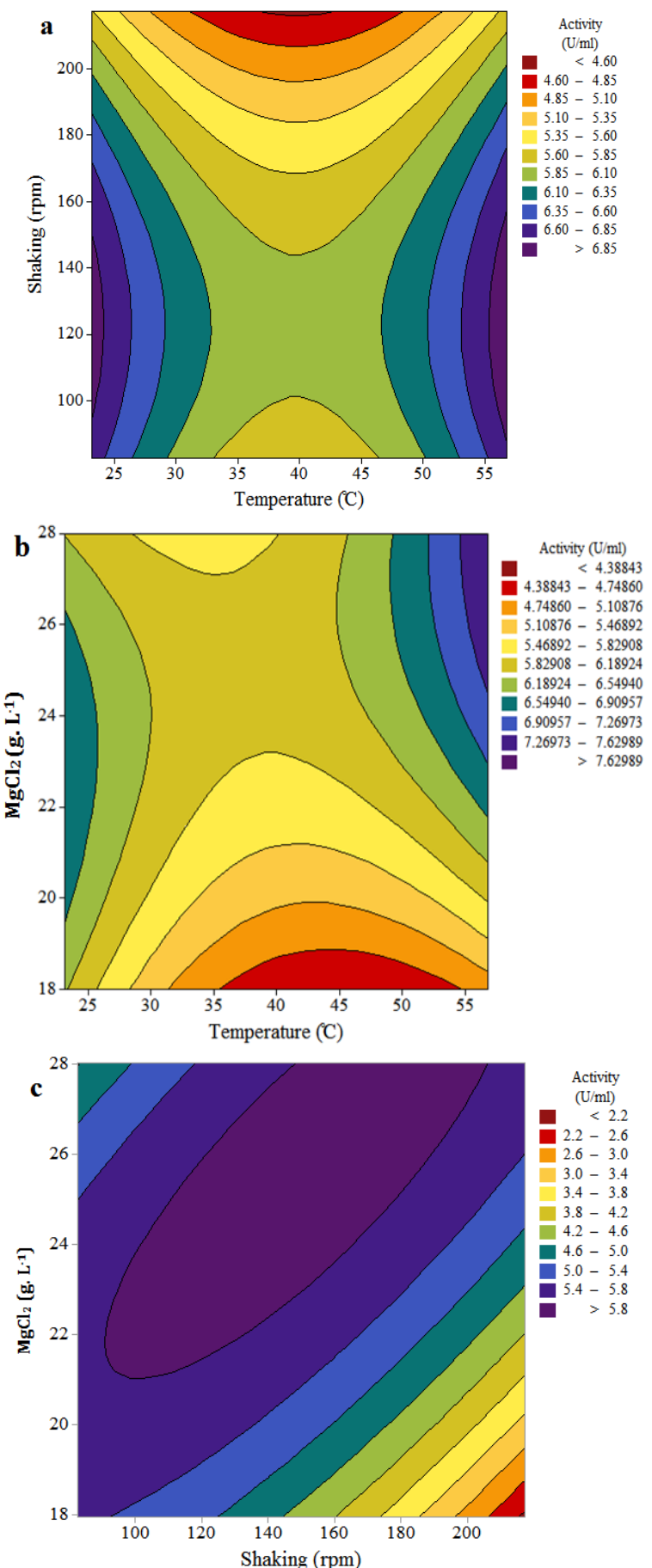

Figure 2 Contour plots of the effect of two variables while the other variable held at 0 level. The $\mathrm{MgCl}_{2}$ concentration, shaking and the temperature held invariant in $\mathrm{a}, \mathrm{b}$ and $\mathrm{c}$, respectively.

\section{CONCLUSIONS}

In the present study, the production of lipase by the halophilic bacterium $N$ asiatica was optimized and modeled. The Placket-Burman design was used for the identification of significant variables affecting lipase production by this bacterium. Among 9 investigated variables, temperature, shaking and $\mathrm{MgCl}_{2}$ concentrations were identified as significant factors. These factors are used as optimization variables using the CCD method in the next step. An increment in lipase production from 3.39 to $6.1 \mathrm{U} \mathrm{mL}^{-1}(79.9 \%)$ was obtained using optimized levels of variables. The maximum lipolysis activity of $N$. asiatica lipase was obtained in $\mathrm{pH} 10$ and so this enzyme was determined as alkaline lipase. Considering the applications of alkaline enzymes and the demands in this field, it seems that $N$. asiatica can be considered and used in the field of biotechnological and industrial processes that are performed under alkaline conditions.

Conflict of Interest: The authors confirm that no part of the manuscript has been plagiarized or self-plagiarized and declare no conflict of interest. 


\section{REFERENCES}

Bhosale, H., Shaheen, U., \& Kadam, T. (2016). Characterization of a Hyperthermostable Alkaline Lipase from Bacillus sonorensis 4R. Enzyme Research, 2016, 1-11. https://doi.org/10.1155/2016/4170684

Burkert, J. (2004). Optimization of extracellular lipase production by Geotrichum sp. using factorial design. Bioresource Technology, 91(1), 77-84. https://doi.org/10.1007/s10295-008-0507-6

Cai, M.-H., Zhou, X.-S., Sun, X.-Q., Tao, K.-J., \& Zhang, Y.-X. (2008) Statistical optimization of medium composition for aspergiolide A production by marine-derived fungus Aspergillus glaucus. Journal of Industrial Microbiology \& Biotechnology, 36(3), 381-389. https://doi.org/10.1007/s10295-008-0507-6

Chennupati, S., Potumarthi, R., Gopal Rao, M., Manga, P. L., Sridevi, M., \& Jetty, A. (2009). Multiple Responses Optimization and Modeling of Lipase Production by Rhodotorula mucilaginosa MTCC-8737 Using Response Surface Methodology. Applied Biochemistry and Biotechnology, 159(2), 317-329. https://doi.org/10.1007/s12010-009-8547-6

Cherif, S., Mnif, S., Hadrich, F., Abdelkafi, S., \& Sayadi, S. (2011). A newly high alkaline lipase: an ideal choice for application in detergent formulations Lipids in Health and Disease, 10(1), 221. https://doi.org/10.1186/1476-511x-10221

Delgado-García, M., Valdivia-Urdiales, B., Aguilar-González, C. N., ContrerasEsquivel, J. C., \& Rodríguez-Herrera, R. (2012). Halophilic hydrolases as a new tool for the biotechnological industries. Journal of the Science of Food and Agriculture, 92(13), 2575-2580. https://doi.org/10.1002/jsfa.5860

Demir, B. S., \& Tükel, S. S. (2010). Purification and characterization of lipase from Spirulina platensis. Journal of Molecular Catalysis B: Enzymatic, 64(3-4), 123-128. https://doi.org/10.1016/j.molcatb.2009.09.011

Elibol, M., \& Ozer, D. (2000). Influence of oxygen transfer on lipase production by Rhizopus arrhizus. Process Biochemistry, 36(4), 325-329. https://doi.org/10.1016/s0032-9592(00)00226-0

Frank Ph. D, J. R. (1992). Experimental design in biotechnology, statistics: Textbooks and monographs, volume 105 Perry D. Haaland Marcel Dekker, Inc., New York, NY, 259 pages [ISBN No.: 0-8247-7881-2] US (1989) Environmental Progress, 11(3), A8-A9. https://doi.org/10.1016/01679473(93)90180-2

Gupta, R., Gupta, N., \& Rathi, P. (2004). Bacterial lipases: an overview of production, purification and biochemical properties. Applied Microbiology and Biotechnology, 64(6), 763-781. https://doi.org/10.1007/s00253-004-1568-8

Hasan, F., Shah, A. A., \& Hameed, A. (2009). Methods for detection an characterization of lipases: a comprehensive review. Biotechnology advances, 27(6), 782-798. https://doi.org/10.1016/j.biotechadv.2009.06.001

Heydari, R., Zahiri, H. S., Noghabi, K. A., Rad, V. V., \& Khaniki, G. B. (2012). A statistical approach to the optimization of cold-adapted amylase production by Exiguobacterium sp. SH3. Starch - Stärke, 64(12), 955-963. https://doi.org/10.1002/star.201200078

Hezayen, F., Rehm, B., Tindall, B., \& Steinbüchel, A. (2001). Transfer of Natrialba asiatica B1T to Natrialba taiwanensis sp. nov. and description of Natrialba aegyptiaca sp. nov., a novel extremely halophilic, aerobic, nonpigmented member of the Archaea from Egypt that produces extracellular poly (glutamic acid). International journal of systematic and evolutionary microbiology, 51(3), 1133-1142. https://doi.org/10.1099/00207713-51-3-1133

Ito, T., Kikuta, H., Nagamori, E., Honda, H., Ogino, H., Ishikawa, H., \& Kobayashi, T. (2001). Lipase production in two-step fed-batch culture of organic solvent-tolerant Pseudomonas aeruginosa LST-03. Journal of Bioscience and Bioengineering, 91(3), 245-250. https://doi.org/10.1016/s1389-1723(01)80128-6 Jaeger, K.-E., \& Eggert, T. (2002). Lipases for biotechnology. Current opinion in biotechnology, 13(4), 390-397. https://doi.org/10.1016/s0958-1669(02)00341-5 Joseph, B., Ramteke, P. W., \& Thomas, G. (2008). Cold active microbial lipases: some hot issues and recent developments. Biotechnology advances, 26(5), 457 470. https://doi.org/10.1016/j.biotechadv.2008.05.003

Karadzic, I., Masui, A., Zivkovic, L. I., \& Fujiwara, N. (2006). Purification and characterization of an alkaline lipase from Pseudomonas aeruginosa isolated from putrid mineral cutting oil as component of metalworking fluid. Journal of Bioscience and Bioengineering, 102(2), 82-89. https://doi.org/10.1263/jbb.102.82 Karan, R., Kumar, S., Sinha, R., \& Khare, S. K. (2012). Halophilic microorganisms as sources of novel enzymes. 555-579. https://doi.org/10.1007/978-94-007-2214-9 25

Litchfield, C. D. (2011). Potential for industrial products from the halophilic Archaea. Journal of Industrial Microbiology \& Biotechnology, 38(10), 1635 https://doi.org/10.1007/s10295-011-1021-9

Liu, J., Zhang, Z., Liu, Z., Zhu, H., Dang, H., Lu, J., \& Cui, Z. (2011) Production of cold-adapted amylase by marine bacterium Wangia sp. C52 Optimization, modeling, and partial characterization. Marine Biotechnology, 13(5), 837-844. https://doi.org/10.1007/s10126-010-9360-5

Margesin, R., \& Schinner, F. (2001). Potential of halotolerant and halophilic microorganisms for biotechnology. Extremophiles, 5(2), 73-83. https://doi.org/10.1007/s007920100184
Mobarak-Qamsari, E., Kasra-Kermanshahi, R., \& Moosavi-Nejad, Z. (2011) Isolation and identification of a novel, lipase-producing bacterium, Pseudomonas aeruginosa KM110. Iranian Journal of Microbiology, 3(2), 92.

Pareek, N., Singh, R. P., \& Ghosh, S. (2011). Optimization of medium composition for enhanced chitin deacetylase production by mutant Penicillium oxalicum SAEM-51 using response surface methodology under submerged fermentation. Process Biochemistry, 46(8), 1693-1697. https://doi.org/10.1016/j.procbio.2011.05.002

Plackett, R. L., \& Burman, J. P. (1946). The design of optimum multifactorial experiments. Biometrika, 33(4), 305. https://doi.org/10.1093/biomet/33.4.305

Prajapati, V. S., Trivedi, U. B., \& Patel, K. C. (2014). A statistical approach for the production of thermostable and alkalophilic alpha-amylase from Bacillus amyloliquefaciens KCP2 under solid-state fermentation. 3 Biotech, 5(2), 211-220. https://doi.org/10.1007/s13205-014-0213-1

Rajendran, A., \& Thangavelu, V. (2007). Sequential optimization of culture medium composition for extracellular lipase production by Bacillus sphaericus using statistical methods. Journal of Chemical Technology \& Biotechnology, 82(5), 460-470. https://doi.org/10.1002/jctb.1691

Sadeghi-Dastjerdi, S., Ebrahimi, M., \& Yalfani, R. (2019). Production of lipase by the deep-sea bacterium Idiomarina zobellii; Identification of effective factors and optimization of production process. Biological Journal of Microorganism, $7(28)$.

Schreck, S. D., \& Grunden, A. M. (2013). Biotechnological applications of halophilic lipases and thioesterases. Applied Microbiology and Biotechnology, 98(3), 1011-1021. https://doi.org/10.1007/s00253-013-5417-5

Sharma, D., Kumbhar, B. K., Verma, A. K., \& Tewari, L. (2014). Optimization of critical growth parameters for enhancing extracellular lipase production by alkalophilic Bacillus sp. Biocatalysis and Agricultural Biotechnology, 3(4), 205211. https://doi.org/10.1016/j.bcab.2014.04.004

Shu, Z. Y., Yang, J. K., \& Yan, Y. J. (2007). Purification and characterization of a lipase from Aspergillus niger F044. Sheng Wu Gong Cheng Xue Bao, 23(1), 96 100. https://doi.org/10.1016/s1872-2075(07)60007-7

Stergiou, P.-Y., Foukis, A., Sklivaniti, H., Zacharaki, P., Papagianni, M., \& Papamichael, E. M. (2012). experimental investigation and optimization of process variables affecting the production of extracellular lipase by Kluyveromyces marxianus IFO 0288. Applied Biochemistry and Biotechnology, 168(3), 672-680. https://doi.org/10.1007/s12010-012-9808-3

Sumrin, A., Ahmad, W., Ijaz, B., Sarwar, M. T., Gull, S., Kausar, H., Hussain, M. (2011). Purification and medium optimization of $\alpha$-amylase from Bacillus subtilis 168. African Journal of Biotechnology, 10(11), 2119-2129.

Tan, C. H., Show, P. L., Ooi, C. W., Ng, E.-P., Lan, J. C.-W., \& Ling, T. C. (2015a). Novel lipase purification methods - a review of the latest developments. Biotechnology Journal, 10(1), 31-44. https://doi.org/10.1002/biot.201400301 Tan, C. H., Show, P. L., Ooi, C. W., Ng, E. P., Lan, J. C. W., \& Ling, T. C. (2015b). Novel lipase purification methods-a review of the latest developments. Biotechnology Journal, 10(1), 31-44. https://doi.org/10.1002/biot.201400301 Tan, T., Zhang, M., Xu, J., \& Zhang, J. (2004). Optimization of culture conditions and properties of lipase from Penicillium camemberti Thom PG-3. Process Biochemistry, 39(11), 1495-1502. https://doi.org/10.1016/s0032 9592(03)00296-6

Thakur, V., Tewari, R., \& Sharma, R. (2014). Evaluation of production parameters for maximum lipase production by Pseudomonas stutzeri MTCC 5618 and scale-up in bioreactor. Chinese Journal of Biology, 2014, 1-14 https://doi.org/10.1155/2014/208462

Uma, J. M. R., \& Satyanarayana, T. (2003). Statistical optimization of a high maltose-forming, hyperthermostable and $\mathrm{Ca}^{2+}$-independent alpha-amylase production by an extreme thermophile Geobacillus thermoleovorans using response surface methodology. Journal of Applied Microbiology, 95(4), 712-718. https://doi.org/10.1046/j.1365-2672.2003.02036.x

Vorderwülbecke, T., Kieslich, K., \& Erdmann, H. (1992). Comparison of lipase by different assays. Enzyme and Microbial Technology, 14(8), 631-639. https://doi.org/10.1016/0141-0229(92)90038-p

Yele, V. U., \& Desai, K. (2014). A New Thermostable and Organic SolventTolerant Lipase from Staphylococcus warneri; Optimization of Media and Production Conditions Using Statistical Methods. Applied Biochemistry and Biotechnology, 175(2), 855-869. https://doi.org/10.1007/s12010-014-1331-2 